\title{
Is it Really Red Versus Blue? Politics, Religion, and the Culture War Within
}

Jody Baumgartner, Peter L. Francia, Jonathan S. Morris, and Carmine P. Scavo

Popular media accounts have suggested there is a culture war raging between residents in red and blue states. Conversely, recent scholarship challenges that position and finds most Americans are not engaged in a culture war, but rather hold moderate positions on controversial social issues. Using public opinion data from the American National Election Study, we attempt to shed further light on the culture war debate. Our findings indicate that there are significant divisions between citizens who hold a literal interpretation of the Bible and those who do not. We conclude that a culture war does not rage between red and blue state residents as popular media accounts often portray; however, there is evidence of polarization within red and blue states with biblical beliefs at the center of this division.

In recent decades, political observers have noted that there are deep opinion differences on social and cultural issues (e.g., abortion and gay marriage) that have divided the American public (see e.g., Hunter 1991; Abramowitz 1995; Frank 2004; Kuckey 2005; Francia and Baumgartner 2005-2006). Some recent publications have examined various sources of political polarization, with a few studies focusing on specific factors, such as regional fragmentation (Black and Black 2007), increased wealth disparity (McCarty, Poole, and Rosenthal 2006), and even the mass media (Mutz 2006) as possible sources. Following the controversial 2000 presidential election and the very competitive 2004 presidential election, many experts pointed to "red" states (which supported Republican George W. Bush) and "blue" states (which supported Democrats Al Gore or John Kerry) as a short-hand reference to illustrate these divisions (see e.g., Lawrence 2002; Dionne 2003; McElvaine 2004).

Despite these numerous accounts of a polarized electorate, others have concluded that public divisions simply do not rise to the level of a "culture war" in the United States (see e.g., Fiorina et al. 2006). This argument follows that the mass media inaccurately attribute deep political

\footnotetext{
**An earlier version of this article was presented at the Annual Meeting of the American Political Science Association, Washington, DC, September 1-4, 2005.

JODY BAUMGARTNER is an assistant professor of political science at East Carolina University. PETER L. FRANCIA is an assistant professor of political science at East Carolina University. JONATHAN S. MORRIS is an assistant professor of political science at East Carolina University. CARMINE P. SCAVO is an associate professor of political science at East Carolina University.
}

The American Review of Politics, Vol. 29, Spring, 2008: 1-18

(C)2008 The American Review of Politics 
divisions that exist among politicians and political activists to members of the general public who are generally moderate and even pragmatic on several of the most controversial social and cultural issues. Polarization, in other words, is confined to a small pool of political elites. Additional research has reported that the importance of social and cultural issues in American elections has been overstated, and that citizens are significantly more likely to base their voting decision on their economic and class interests (Bartels 2006; Brewer and Stonecash 2007).

In light of this ongoing debate, and given the prevalence of the "red state-blue state" paradigm in the popular press, there are several questions that remain unanswered. For example, if there is a red state-blue state divide, then what exactly underlies these divisions? Or, if the red state-blue state divide has been exaggerated by political pundits, are there other divisions that may exist within red and blue states?

Our purpose in this study is to shed light on these questions. Our results indicate that while a culture war does not rage between citizens in red states and those in blue states, there is a religious conflict within both red and blue states. We find that on certain issues the United States is comprised of citizens with strong and divided feelings on issues such as abortion and homosexuality, with these differences rooted in biblical beliefs. Specifically, we find that biblical interpretation drives polarization within red and blue states on social and cultural issues.

\section{A 50:50 Nation on Social and Cultural Issues?}

Two of the most high-profile social and cultural issues in recent elections have been abortion and the rights of homosexuals. One of the top stories immediately following the 2004 election were exit poll results that showed voters citing "moral values" as the most important political issue with more frequency than the economy, terrorism, the war in Iraq, health care, or education (National Exit Poll 2004). ${ }^{1}$ This was a surprise to many experts who speculated that positions on more traditional domestic and foreign policy issues would drive vote choice.

Many scholars have since taken issue with how these polls were conducted (Hillygus and Shields 2005); however, there is evidence that shows so-called "values-voters" were heavily mobilized because of the saliency of the gay marriage issue in the 2004 presidential election. Voter turnout, for instance, increased by 3.9 percentage points in the eleven states with same sex marriage initiatives compared to 0.8 percentage points in the 39 states that did not have such initiatives (Jackman 2004). Interestingly, Jackman's analysis also shows that while turnout increased more in same sex marriage initiative states than in those that did not have such initiatives, the increase 
in turnout did not favor the re-election of George Bush (but see also Campbell and Monson 2005). The presence of same sex marriage initiative on the ballot increased turnout from both those who had strong feelings in favor of - and opposition to - same sex marriage, thereby illustrating the divisive nature of values issues.

Likewise, abortion has been one of the most contentious issues over the past three decades, inspiring political marches, protests, and in extreme cases, criminal violence. As Jelen and Wilcox $(2003,489)$ observe in a recent article, "[M]ost Americans have an opinion on abortion, and a substantial majority indicate that the issue is important to them." A significant number of studies find that abortion inspires increased political activity (Verba, Schlozman, and Brady 1995) and affects individual voting behavior in elections for virtually all offices (Cook et al. 1994; Smith 1994; Abramowitz 1995). It also has been shown to be an increasingly polarizing issue among Americans (DiMaggio, Evans, and Bryson 1996; but see also Mouw and Sobel 2001).

Most studies further document that public opinion on abortion is situational in that Americans may support abortion in some instances, but not others (O'Connor 1996; Sullins 1999). Nevertheless, while abortion politics has significant nuances to it, voters and candidates typically define their own positions as simply pro-life or pro-choice. Framed in these terms, there is evidence of a 50:50 nation on the abortion issue. As Figure 1 illustrates, virtually half of the nation from 1980 to 2004 either falls on the pro-life side (abortion should never be permitted or the law should permit abortion only in case of rape, incest, or when the woman's life is in danger) or the prochoice side (abortion should be allowed for reasons other than rape, incest, or danger to the woman's life, or for any reason as a matter of personal choice). These results confirm quite stable 50:50 divisions on the abortion issue over time.

Similarly, there is almost an equal split in the nation on whether homosexuals should be permitted to adopt children (see Figure 2). While a solid majority of roughly seven of ten Americans once opposed this in 1992, the issue has become decidedly more divisive in recent years. As of 2004, 48 percent of Americans opposed gay adoption compared to 47 percent who supported it - results that certainly approximate what we would expect in a 50:50 nation.

In addition, the most salient current issue concerning gay rights is unquestionably the matter of same-sex marriage. While the American National Election Study does not contain sufficient data to track public opinion on this issue over time, the Gallup Poll does. As Figure 3 illustrates, there was widespread agreement on the issue in 1996. Nearly seven of ten Americans answered that the law should not recognize marriages between same-sex 
Figure 1. A 50:50 Nation on Abortion? Question: When should abortion be allowed?

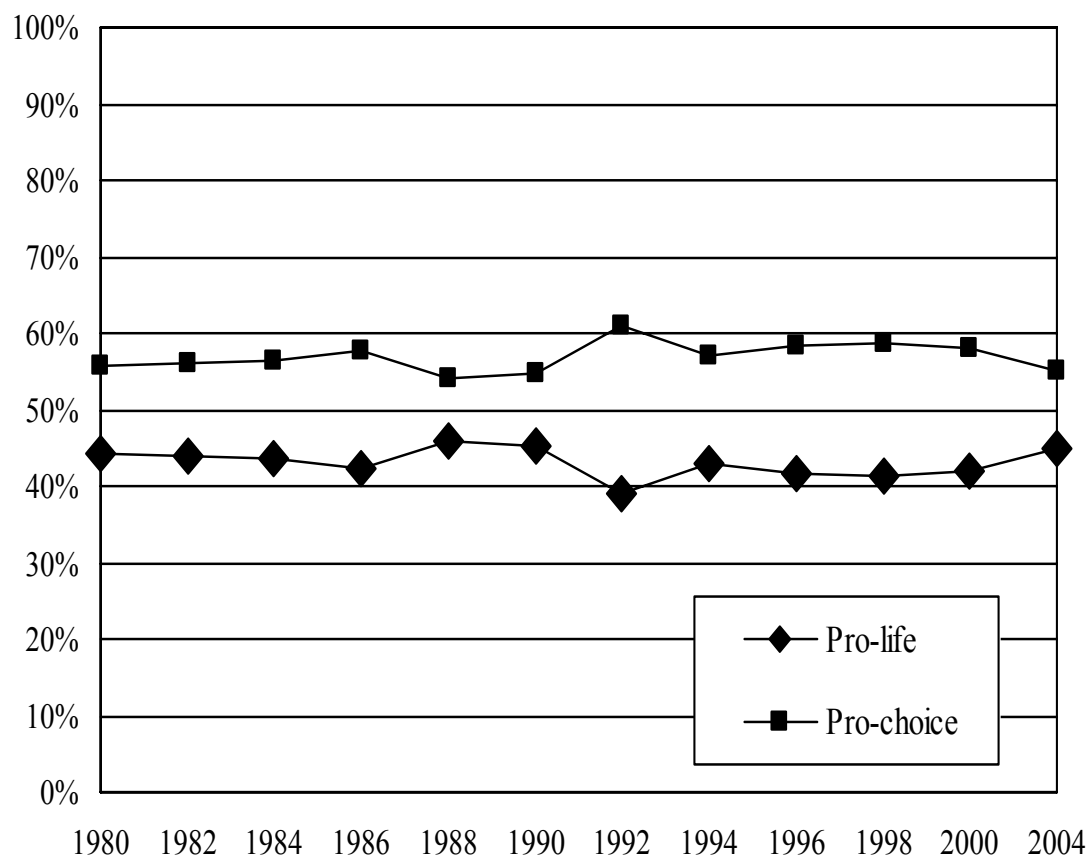

Notes: Pro-life respondents are defined as those who answered, "By law, abortion should never be permitted" or "The law should permit abortion only in case of rape, incest, or when the woman's life is in danger." Pro-choice respondents are defined as those who answered, "The law should permit abortion for reasons other than rape, incest, or danger to the woman's life, but only after the need for the abortion has been clearly established" or "By law, a woman should always be able to obtain an abortion as a matter of personal choice."

Source: American National Election Study (cumulative file).

couples as valid compared to less than three in ten of respondents who answered that same-sex marriages should be legally valid. By 2007, however, there was significantly greater division. According to Gallup, 53 percent of Americans now believe that same-sex marriage should be illegal compared to 46 percent who think that it should be legal. Again, the trend on this issue closely resembles a 50:50 nation.

To be clear, not every social and cultural issue has moved in a more divisive direction. For example, allowing gays in the military now draws strong support from most Americans, unlike in the early 1990s when opinion was more divided. Nevertheless, a culture war does not need to be fought on a multitude of issues. Indeed, even one highly salient issue can be sufficient 
Figure 2. A 50:50 Nation on Gay Adoption? Question: Should gays/lesbians be able to adopt children?

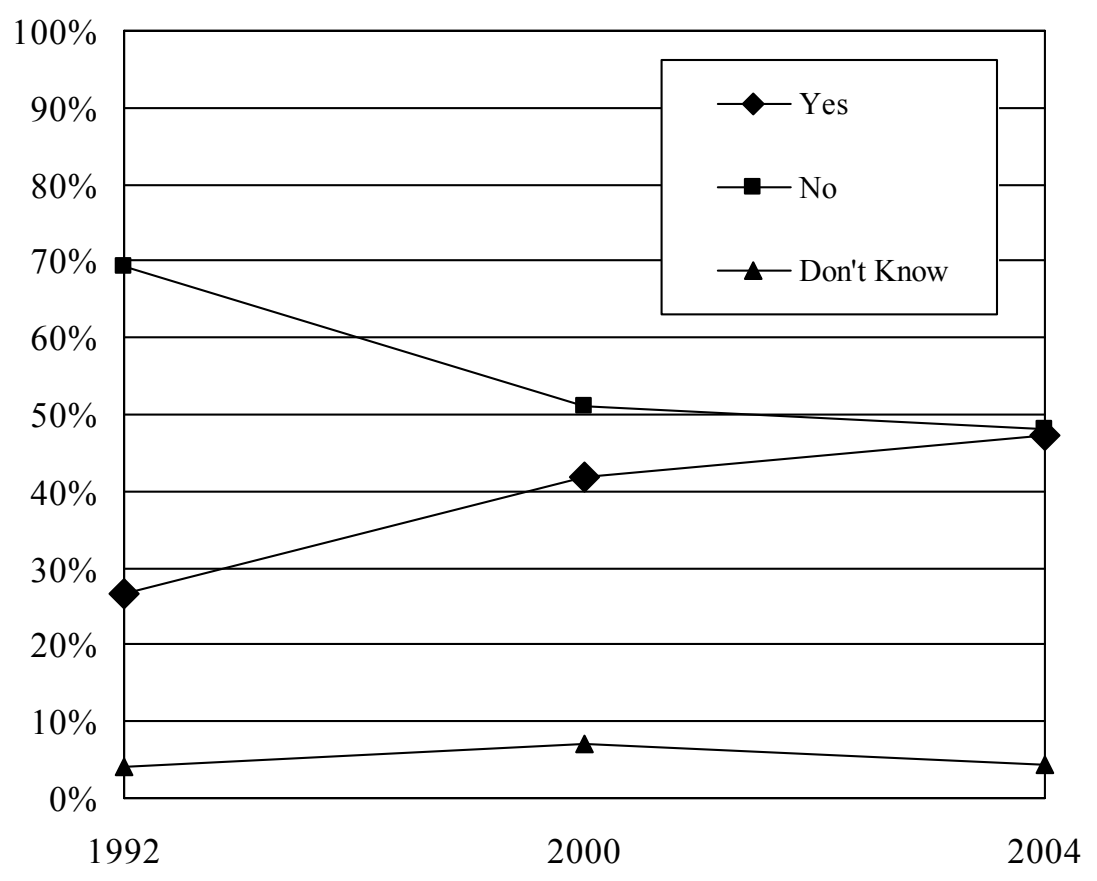

Source: American National Election Study (cumulative file).

to drive polarization. In 2004, the abortion issue, while not attracting major headlines, was very to extremely important to six of ten Americans and to roughly two of every three voters according to data from the American National Election Study. And, as cited previously, exit poll data showed "moral values" as a major issue of concern to many voters in 2004. Although there were legitimate criticisms that the media too loosely interchanged "moral values" with gay marriage, most critics of the exit poll have acknowledged that "moral values" would broadly apply to a myriad of issues concerning the culture war, including abortion, gay rights, and even the role of women in society and the family. Thus while "gay marriage" may not have specifically been the top issue, the broader concerns that encompass the so-called "culture war" combined to be a fairly prominent force in the 2004 election.

Taken together, there appears to be some evidence of an evenly divided and a deeply divided public on at least a few social and cultural issues. The source of these divisions, however, remains an open question. Is the nation 
Figure 3. A 50:50 Nation on Gay Marriage? Question: Do you think marriages between same-sex couples should or should not be recognized by the law as valid, with the same rights as traditional marriages?

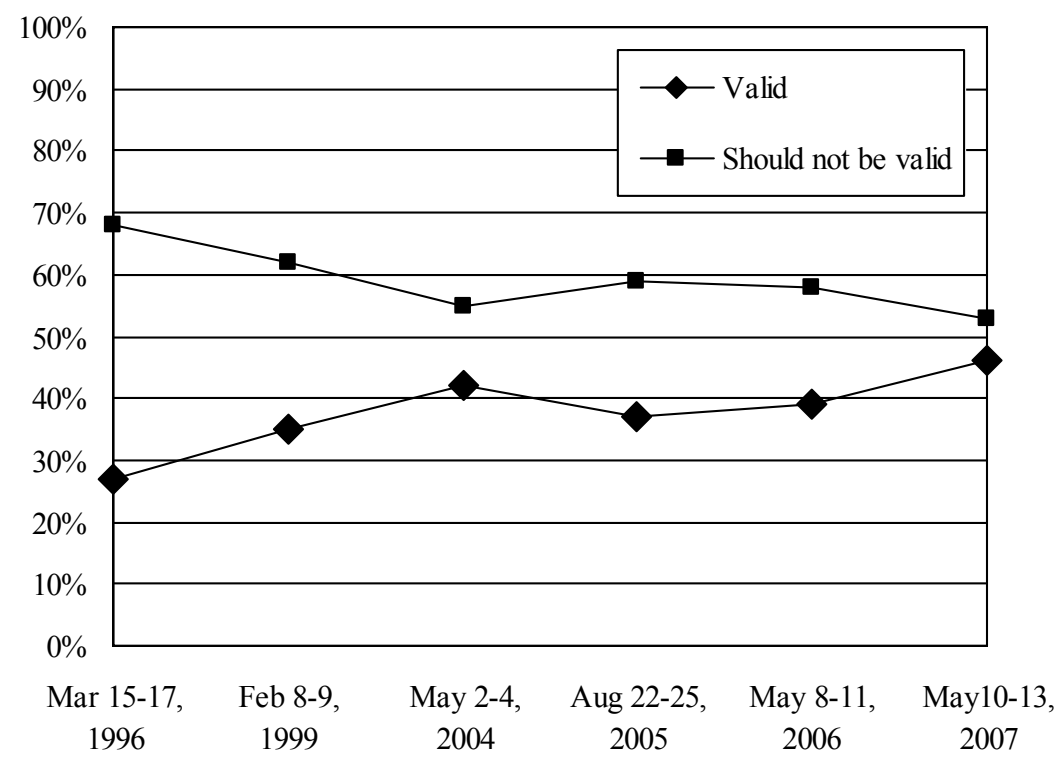

Source: "Homosexual Relations," Gallup Poll, http://www.galluppoll.com/content/?CI=165 (accessed September 26, 2007).

divided along red state and blue state lines? Or, are there other better explanations? We argue that better explanations do exist—-specifically that biblical beliefs play a defining role in polarizing Americans on social and cultural issues. In addition, we contend that the red state-blue state argument that has become so frequent among pundits and the popular press is too simplistic and misses an important point, namely, that states are not homogeneous. It certainly seems plausible to us that within-state variations in attitudes and behaviors are greater than between-state variations.

\section{Religious Beliefs as a Source of Polarization in the Culture War}

Virtually any serious discussion of the culture war must begin with a discussion of religion. Evangelical Christians and other religious traditionalists have spent decades citing the breakdown of moral and traditional values in the United States (see e.g., Hunter 1991; Jelen 1991; Green and Guth 
1991; Green, Guth, and Hill 1993; Layman and Carmines 1997; Layman 2001; White 2003). As E.J. Dionne recently noted, "If not all of the polarization in American politics can be explained by attitudes toward religious faith, a significant part of it certainly can be" $(2006,176)$.

Most studies that have examined the influence of religion on polarization have focused on church attendance. A study by Glaeser, Ponzetto, and Shapiro $(2004,5)$ found that "religious determinants of political orientation will be maximized when about 50 percent of the population attends church regularly." That is, in states, such as a California, where close to 50 percent of the population attends church once per month or more, and the other half does not, there is a strong relationship church attendance and voting behavior. The Gallup Organization also did an extensive report on the effect of church attendance, and found that it was a significant national determinant of political attitudes and behavior during the 2004 presidential election (see Newport 2005; see also Pew Center for People and the Press 2001). Abramowitz and Saunders (2005) and Olson and Green (2006) similarly found significant differences on a variety of political issues based on church attendance.

As these recent findings make clear, church attendance is responsible for at least some level of division in American politics - a point acknowledged even by those who suggest that polarization is largely a myth (see e.g., Fiorina et al. 2006, chp. 6). However, while the measure for church attendance provides for some robust results, it fails to differentiate between the different philosophies and teachings of various religions. As many studies have documented, religious philosophies and teachings are not uniform across or even within different religions (see e.g., Wuthnow 1988).

One approach to differentiate between religious philosophies and teachings is to examine denominational affiliation. Political differences, however, among Christians, Jews, and Protestants have declined in recent years (Green and Guth 1991; Hunter 1991; Kellstedt and Smidt 1996). Instead, divisions within denominations - specifically between a church's "liberal" and "conservative" wings - may provide for more meaningful differences, especially with respect to analyzing how religious beliefs shape political attitudes and behavior (Layman 1997; Hutcheson and Shriver 1999; Rozell, Wilcox, and Green 1998). Very often these ideological debates are based on disagreements over interpretation of scripture - specifically with respect to whether the Bible should be interpreted literally or not (Spong 1991).

Biblical literalists typically reject any scientific claims that may conflict with biblical accounts (e.g., evolution). They believe that all of the detailed accounts found in the Bible are historically accurate, that the Bible is the literal and inerrant word of God (Marsden 1980; Ammerman 1987). Biblical literalists have often clashed with non-literalists on political issues through- 
out the past century. Perhaps the most famous was the "Scopes" or "Great Monkey" trial in 1925 in which the state of Tennessee, with the avid support of biblical literalists, brought charges against John Thomas Scopes for teaching evolution in a public school (see Larson 1997). ${ }^{2}$

In later years, biblical literalists would become vocal leaders against communism, the "counter culture" of the 1960s, and feminism (Tedin et al. 1977; Cook, Jelen, and Wilcox 1992). By the 1980s and 1990s, literalists organized in opposition to abortion and were vocal proponents of reinstituting prayer in public schools (Wilcox and Larson 2006). Since 2000, banning gay marriage and government funding of embryonic stem cell research have become significant issues among this constituency. While the issues may change over time, literal interpretation of biblical scripture has remained at the heart of numerous political divisions since the early 1900s.

On the most pressing social and cultural issues of the last decade, biblical literalists have continued to rely on the Bible to justify their positions. Biblical literalists, for instance, invoke numerous parts from the Bible on the abortion issue. One example is the passage from Deuteronomy 27:25, which states, "Cursed be he that taketh reward to slay an innocent person." To literalists, the unborn are innocent lives, and thus abortion represents a violation of biblical teachings. On the issue of homosexuality and gay marriage, biblical literalists commonly cite Leviticus 18:22 ("And with a man you shall not lie with as a man lies with a woman; it is an abomination") to defend their opposition.

Interestingly, the public almost divides evenly over biblical interpretation. According to the 2004 American National Election Study, roughly two of every five Americans are biblical literalists. In blue states, literalists comprise a smaller, but still sizable minority of three in ten people. In red states, biblical literalists constitute a majority of the population at 51 percent (see Table 1). The literalist and non-literalist camps are therefore large enough blocs to create a polarized political environment in both red and blue states. Indeed, we hypothesize that this is the case. Specifically, we expect to demonstrate that there is evidence of a culture war within red and blue states, which has its foundation based in differences related to biblical interpretation.

\section{Data and Methods}

We use data from the 2004 American National Election Study (ANES) to test for the possible polarization effects of biblical interpretation on social and cultural issues in red and blue states. Our primary explanatory variable, biblical literalist, is coded 1 if the respondent answered that, "The Bible is the actual word of God and is to be taken literally, word for word." It is 


\section{Table 1. The Percentage of Bible Literalists in Red and Blue States, 2004}

\begin{tabular}{lcc}
\hline Variables & Red State & Blue State \\
\hline Bible literalists & $51 \%$ & $29 \%$ \\
Non-literalists & $49 \%$ & $71 \%$ \\
(N) & $(538)$ & $(649)$ \\
Note: Biblical literalists are defined as those who answered that, "The Bible is the actual word of \\
God and is to be taken literally, word for word." \\
Source: American National Election Study, 2004. \\
\hline
\end{tabular}

coded 0 if the respondent answered, "The Bible is the word of God but not everything in it should be taken literally, word for word" or "The Bible is a book written by men and is not the word of God."

In our analysis, we also consider the effects of red state-blue state divisions in the electorate. Respondents who live in a state where Republican George W. Bush won in 2004 are defined as "red" state residents. Respondents who live in a state where Democrat John Kerry won in 2004 are defined as "blue" state residents. ${ }^{4}$ We control for numerous socio-economic and demographic factors that may influence public opinion and attitudes on various social and cultural issues. These controls include party identification, gender, race, education, income, marital status, and age (see Appendix for information on the coding of each variable). ${ }^{5}$

We examine a series of eight social and cultural issues that include government funding of abortion, partial-birth abortion, gay marriage, laws to protect homosexuals, gays in the military, gay adoption, women's equality, and the role of women in society. These issues have been dominant in previous research examining the culture war (see e.g., Hunter 1991; Kaufmann 2002; Fiorina et al. 2006). Seven of these questions are coded on an ordinal scale, and are tested using ordered probit analysis. The gay adoption question is a binary variable and is tested using probit analysis. All eight dependent variables have been coded so that the highest value reflects the most conservative position.

\section{A Polarized America? Evidence from 2004}

As hypothesized, the results demonstrate that biblical interpretation is a driving force behind polarization on cultural issues (see Table 2). Biblical literalism is a significant predictor of culturally conservative positions on all eight issues, even when controlling for various factors including party identification and other socio-economic and demographic factors. More 
$10 \mid$ J. Baumgartner, P.L. Francia, J.S. Morris, and C.P. Scavo

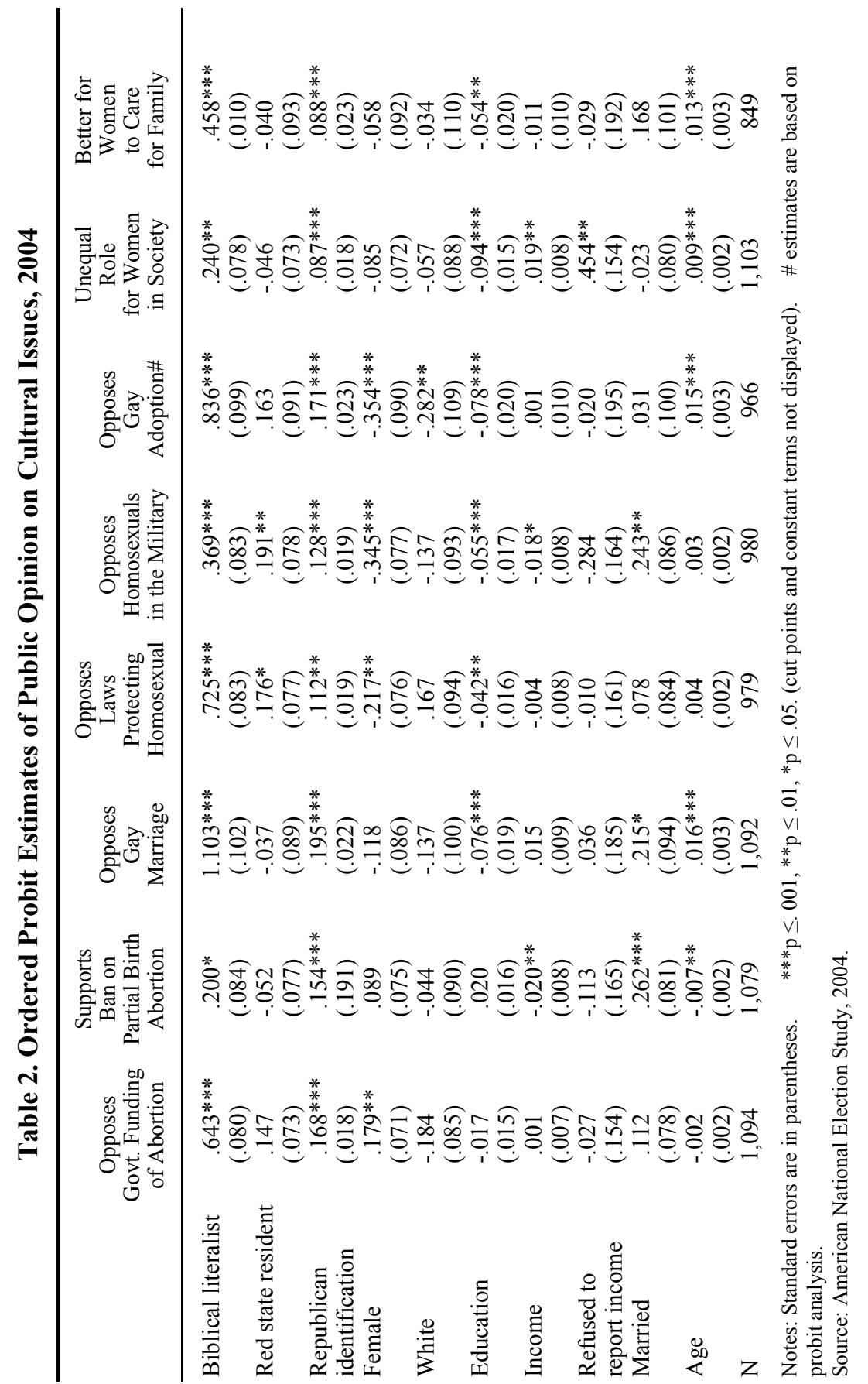


specifically, the predicted probabilities indicate that an estimated 70 percent of typical voters ${ }^{6}$ who are biblical literalists and reside in red states strongly oppose government funding of abortion (see Table 3 ). ${ }^{7}$ However, this strong opposition drops by 25 percentage points in red states among typical voters who are non-literalists. Only 45 percent of non-literalists in red states strongly oppose government funding of abortion. These patterns are consistent in blue states. An estimated 64 percent of biblical literalists strongly oppose government funding of abortion compared to 39 percent of nonliteralists in blue states. We also find smaller, but statistically significant gaps on the issue of partial birth abortion between literalists and nonliteralists in red states and blue states.

On issues involving the rights of homosexuals, the gap between biblical literalists and non-literalists is very pronounced. An estimated 86 percent of biblical literalists in red states oppose gay marriage compared to 50 percent of non-literalists in red states. An equal gap of 36 percentage points divides literalists from non-literalists in blue states. Large, double-digit differences also separate literalists and non-literalists in red and blue states on the issue of laws protecting homosexuals and the issue of gays in the military. Women's issues further constituted healthy differences of 9 points between literalists and non-literalists on the issue of women's equality in red and blue states, and 16 points and 17 points on the issue of women's role in society in red and blue states respectively.

Of course, a cynical reading of these results might note that the analysis relies on the 2004 election only. To be thorough, we also examined some patterns over time to establish that the 2004 election was not exceptional, but rather consistent with the patterns in other elections. Using data from the American National Election Study, we found that polarization has been and remains pronounced between biblical literalists and non-literalists on abortion since 1980 (see Figure 4). Polarization between biblical literalists and non-literalists has even grown on the issue of gay adoption since 1992 (see Figure 5). These results all suggest that there is some degree of polarization in the electorate, and it has existed along the lines of biblical beliefs for some time regardless of red state and blue state boundaries.

\section{Discussion}

Our results lead us to conclude that Americans are not as moderate on social and cultural issues as some scholars have suggested. Abortion and homosexuality invoke near even 50:50 divisions, as well as strong opinions from an overwhelming proportion of the electorate. Many recent press accounts, however, have confused the sources of conflict on social and cultural issues by focusing on divisions between red and blue state residents. 
Table 3. Predicted Probabilities for Public Opinion on Cultural Issues

\begin{tabular}{|c|c|c|c|c|}
\hline & Red $s$ & State & Blue & State \\
\hline & Literalists & Non-literalists & Literalists & Non-literalists \\
\hline $\begin{array}{l}\text { Strongly oppose government } \\
\text { funding of abortion }\end{array}$ & $70 \%( \pm 3 \%)$ & $45 \%( \pm 3 \%)$ & $64 \%( \pm 4 \%)$ & $39 \%( \pm 3 \%)$ \\
\hline $\begin{array}{l}\text { Strongly support a ban } \\
\text { on partial birth abortion }\end{array}$ & $66 \%( \pm 4 \%)$ & $58 \%( \pm 4 \%)$ & $68 \%( \pm 4 \%)$ & $60 \%( \pm 4 \%)$ \\
\hline Oppose gay marriage & $86 \%( \pm 3 \%)$ & $50 \%( \pm 4 \%)$ & $87 \%( \pm 3 \%)$ & $51 \%( \pm 4 \%)$ \\
\hline $\begin{array}{l}\text { Strongly support laws } \\
\text { protecting homosexuals }\end{array}$ & $29 \%( \pm 3 \%)$ & $57 \%( \pm 2 \%)$ & $36 \%( \pm 4 \%)$ & $64 \%( \pm 3 \%)$ \\
\hline $\begin{array}{l}\text { Strongly support homo- } \\
\text { sexuals in the military }\end{array}$ & $43 \%( \pm 4 \%)$ & $58 \%( \pm 3 \%)$ & $51 \%( \pm 4 \%)$ & $65 \%( \pm 3 \%)$ \\
\hline Favors gay adoption & $33 \%( \pm 4 \%)$ & $65 \%( \pm 4 \%)$ & $39 \%( \pm 4 \%)$ & $71 \%( \pm 3 \%)$ \\
\hline $\begin{array}{l}\text { Strongly agree that men } \\
\text { and women should have } \\
\text { equal roles }\end{array}$ & $59 \%( \pm 4 \%)$ & $68 \%( \pm 3 \%)$ & $58 \%( \pm 4 \%)$ & $67 \%( \pm 3 \%)$ \\
\hline $\begin{array}{l}\text { Disagree it is better for } \\
\text { women to care for family } \\
\text { and for the man to achieve }\end{array}$ & $59 \%( \pm 4 \%)$ & $75 \%( \pm 4 \%)$ & $57 \%( \pm 5 \%)$ & $74 \%( \pm 3 \%)$ \\
\hline $\begin{array}{l}\text { Note: The predicted probabilitie } \\
\text { Clarify to generate the estimates } \\
\text { standard errors generated by Clar } \\
\text { Source: American National Elect }\end{array}$ & $\begin{array}{l}\text { are based on t } \\
\text { ee Tomz, Witt } \\
\text { are in parenth } \\
\text { Study, 2004. }\end{array}$ & $\begin{array}{l}\text { he multivariate } \\
\text { enberg, and Kin } \\
\text { eses. }\end{array}$ & $\begin{array}{l}\text { ults in Tables } \\
001 \text { for more }\end{array}$ & $\begin{array}{l}\text { 3. We relied on } \\
\text { information). The }\end{array}$ \\
\hline
\end{tabular}

Red state-blue state divisions are minimal. However, this certainly does not preclude the possibility that other factors may be driving polarization within red and blue states. As our results demonstrate, there is significant conflict between biblical literalists and non-literalists within red and the blue states.

This finding is important to recognize because it sheds some light on what makes a state red and what may tip a state blue. Biblical literalists are a much stronger voting bloc in the red states. This would suggest that candidates who espouse conservative views, especially on social issues, stand a good chance of winning election in these states given that biblical literalists are staunchly conservative on most cultural issues. By comparison, biblical literalists are a much weaker voting bloc in the blue states. This religious balance may explain why political outcomes have been different in blue states than they have been in red states. 
Figure 4. Religious Polarization Among Those Who Are Pro-Choice

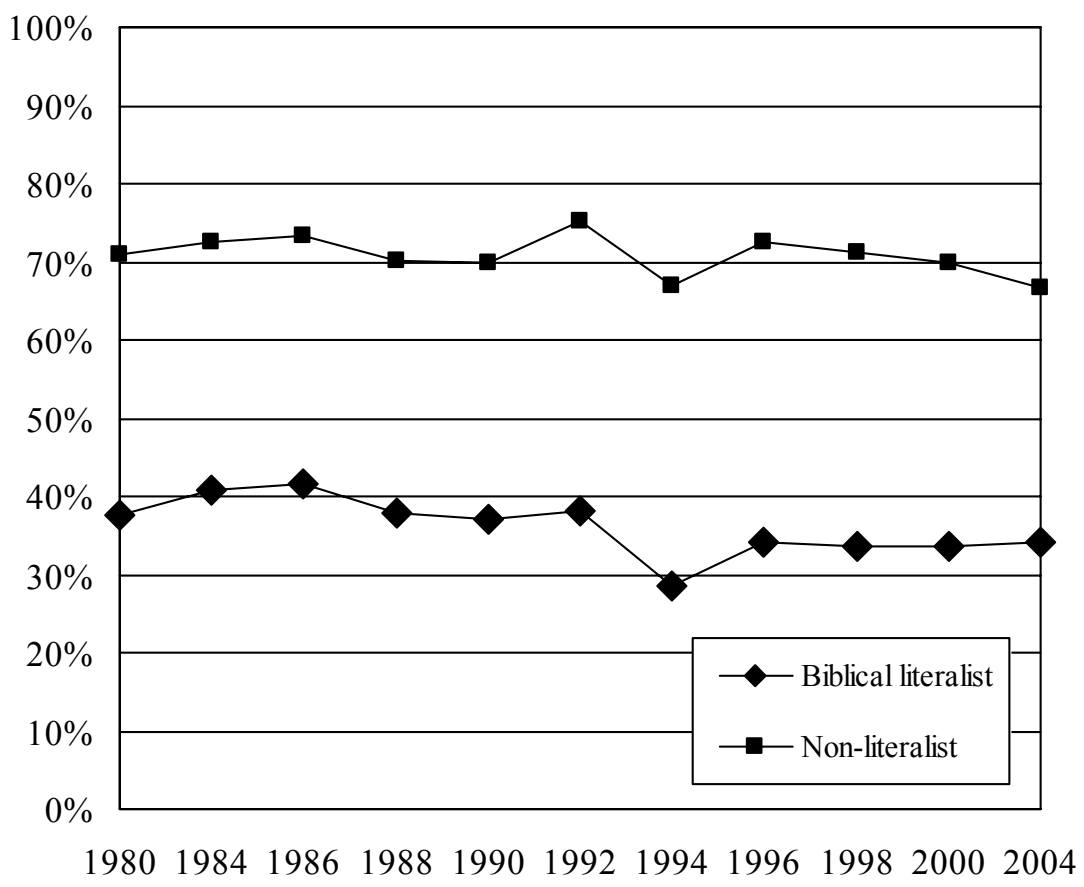

Source: American National Election Study (cumulative file).

Our analysis also suggests that polarization may not be an entirely elitedriven phenomenon, as Fiorina et al. claim. Certainly, we would acknowledge that political leaders and candidates, such as President George W. Bush (who often discusses the significance of his "born-again" experience and has taken positions consistent with biblical literalists on issues such as evolution), played a significant role in dividing Americans during the 2004 election (see e.g., Jacobson 2007). Indeed, 72 percent of white biblical literalists voted for George W. Bush compared to 28 percent who voted for John Kerry.

However, as our results demonstrate, George W. Bush was not the only divisive element of the 2004 election - the public was divided on several social and cultural policy issues. The polarization of the electorate on social and cultural issues suggests that biblical beliefs may play at least some role in pushing Republican candidates to the right. At a minimum, Republican candidates have a powerful incentive to adopt conservative positions on cultural issues in areas where biblical literalists are strongest. Future research 


\section{Figure 5. Religious Polarization Among Those Who Believe Homosexuals Should Be Permitted to Adopt Children}

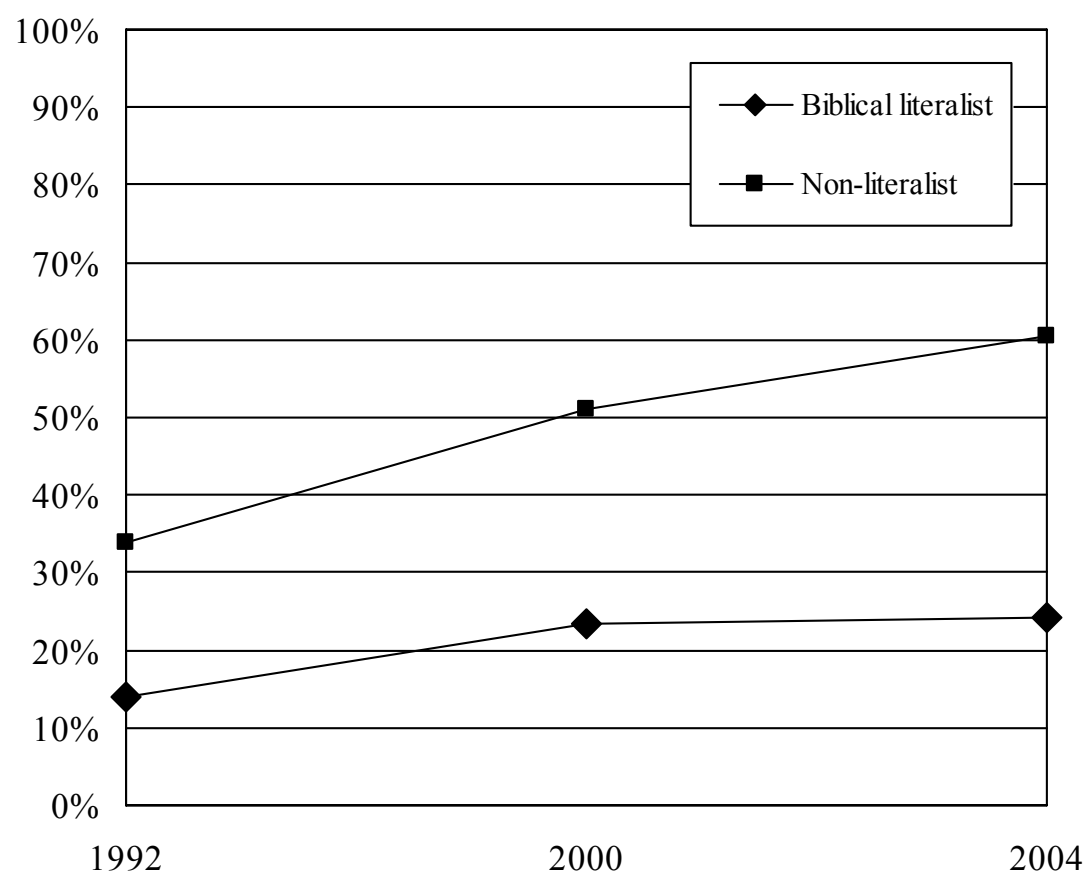

Source: American National Election Study (cumulative file).

should build on this study by more directly examining whether politicians are responding to the public, whether the public is responding to cues from elites, or more likely, both. Also, future research could examine the importance of religious polarization on issues beyond those that are social or cultural.

In addition to the need for future research, our results present some further issues to consider, such as whether the differences presented in this study might qualify as evidence of a culture war. Fiorina et al. often go to great lengths to criticize the term "war" in describing the differences that separate Americans on social and cultural issues. Given our results, we would readily concede that "war" certainly borders on hyperbole. Nevertheless, while polarization may not rise to the level of a war, there certainly appears to be significant conflict within the electorate on cultural issues. As our results demonstrate, the driving force behind this conflict is rooted in biblical beliefs, regardless of red and blue state boundaries. 


\section{APPENDIX Variable Definitions}

Age: Based on question V043250 of the 2004 ANES. Coded based upon the age of the respondent.

Biblical literalist: Based on question V043222 of the 2004 ANES. Coded 1 if the respondent answered that, "The Bible is the actual word of God and is to be taken literally, word for word;" coded 0 if the respondent answered, "The Bible is the word of God but not everything in it should be taken literally, word for word" or "The Bible is a book written by men and is not the word of God."

Did not answer income: Based on question V043293x of the 2004 ANES. Coded 1 if the respondent refused or did not provide an answer for his or her annual income; 0 otherwise.

Education: Based on question V043252 of the 2004 ANES. Based upon the highest grade that respondent complete (e.g., 11th grade is coded as 11, 12th grade as 12, etc. Graduate education is coded 17).

Female: Based on question V041109a of the 2004 ANES. Coded 1 if the respondent is female and coded 0 if the respondent is male.

Income: Based on question V043293x of the 2004 ANES. Coded as follows: 1. None or less than $\$ 2,999 ; 2$. $\$ 3,000-\$ 4,999 ; 3$. \$5,000 -\$6,999; 4. \$7,000 -\$8,999; 5. \$9,000 -\$10,999; 6. \$11,000-\$12,999; 7. \$13,000-\$14,999; 8. \$15,000-\$16,999; 9. \$17,000$\$ 19,999 ; 10$. \$20,000-\$21,999; 11. \$22,000-\$24,999; 12. \$25,000-\$29,999; 13. $\$ 30,000-\$ 34,999 ; 14$. \$35,000-\$39,999; 15. \$40,000-\$44,999; 16. \$45,000-\$49,999; 17. $\$ 50,000-\$ 59,999 ; 18$. $\$ 60,000-\$ 69,999 ; 19$. $\$ 70,000-\$ 79,999 ; 20$. $\$ 80,000-$ $\$ 89,999 ; 21$. $\$ 90,000-\$ 104,999 ; 22$. $\$ 105,000-\$ 119,000 ; 23 . \$ 120,000$ and over.

Married: Based on question V043251 of the 2004 ANES. Coded 1 if the respondent is married; 0 otherwise.

Red state resident: Coded 1 if the respondent resided in a state that George W. Bush won during the 2004 election; coded 0 if John Kerry was the winner.

Republican identification: Based on question V043116 of the 2004 ANES. Coded as follows: 0. Strong Democrat; 1 . Weak Democrat; 2. Independent-Democrat; 3. Independent-Independent; 4. Independent-Republican; 5. Weak Republican; 6. Strong Republican.

White: Based on question V043299 of the 2004 ANES. Coded 1 if the respondent is white; 0 otherwise.

\section{NOTES}

${ }^{1}$ Fiorina, et al. show that while $21.8 \%$ (largest percentage) of respondents cited moral values as the most important issue, $19.7 \%$ cited the economy/jobs, $18.9 \%$ cited terrorism, and $14.7 \%$ cited Iraq (see their Table 8.1, 146).

${ }^{2}$ In this famous case, the state of Tennessee brought charges against John Thomas Scopes for teaching evolution in a public school. Scopes was ultimately found guilty, but he later appealed the verdict, and the Tennessee state supreme court overturned the conviction (see Larson 1997).

${ }^{3}$ In an earlier version of the paper, we created a religion measure using factor analysis of six religion questions asked in the 2004 ANES. The results, however, were 
virtually identical to those presented in this study, which rely on biblical interpretation. We ultimately chose to present the biblical interpretation results based upon the principle of Ockham's Razor, which instructs that "entities should not be multiplied unnecessarily."

${ }^{4}$ We use the red state-blue state map from 2004 because the ANES study that we use was taken in 2004.

${ }^{5}$ Several respondents refused to answer the income question. To preserve those cases, we added a dummy variable to our models reflecting those who refused to report their income.

${ }^{6}$ A typical voter is defined by setting Republican identification, education, income, and age at the mean. For binary variables, we chose the modal values (i.e., female, white, and married).

${ }^{7}$ Predicted probabilities and standard errors were generated using Clarify. For more information, see King, Tomz, and Wittenberg (2000) and Tomz, Wittenberg, and King (2001).

\section{REFERENCES}

Abramowitz, Alan I. 1995. It's Abortion Stupid: Policy Voting in the 1992 Presidential Election. Journal of Politics 57:176-186.

Abramowitz, Alan, and Kyle Saunders. 2005. Why Can't We All Just Get Along? The Reality of a Polarized America. The Forum 3(2), Article 1.

Ammerman, Nancy Tatom. 1987. Bible Believers: Fundamentalists in the Modern World. New Brunswick, NJ: Rutgers University Press.

Bartels, Larry. 2006. What's the Matter with What's the Matter with Kansas? Quarterly Journal of Political Science 1:201-226.

Black, Earl, and Merle Black. 2007. Divided America: The Ferocious Power Struggle in American Politics. New York: Simon \& Schuster.

Brewer, Mark D., and Jeffrey M. Stonecash. 2007. Split: Class and Cultural Divides in American Politics. Washington, DC: CQ Press.

Campbell, David, and J. Quin Monson. 2005. The Religion Card: Evangelical, Catholics, and Gay Marriage in the 2004 Presidential Election. Presented at the Annual Meeting of the American Political Science Association, Washington, DC.

Cook, Elizabeth Adell, Ted G. Jelen, and Clyde Wilcox. 1992. Between Two Absolutes: American Public Opinion and the Politics of Abortion. Boulder, CO: Greenwood.

Cook, Elizabeth Adell, Ted G. Jelen, and Clyde Wilcox. 1994. Issue Voting in U.S. Senate Elections: The Abortion Issue in 1990. Congress and the Presidency 21:99-112.

DiMaggio, Paul, John Evans, and Bethany Bryson. 1996. Have Americans' Social Attitudes Become More Polarized? American Journal of Sociology 102:690-755.

Dionne, E.J., Jr. 2003. One Nation Deeply Divided. Washington Post, Nov. 7, p. A31.

Dionne, E.J., Jr. 2006. Polarized by God? American Politics and the Religious Divide. Pp. 175-205 in Red and Blue Nation?, eds. Pietro S. Nivola and David W. Brady. Washington, DC: Brookings.

Fiorina, Morris P., Samuel J. Abrams, and Jeremy C. Pope. 2006. Culture War? The Myth of a Polarized America, 2nd ed. New York: Pearson-Longman.

Francia, Peter L., and Jody C. Baumgartner. 2005-2006. Victim or Victor of the "Culture War"? How Cultural Issues Affect Support for George W. Bush in Rural America. American Review of Politics 26:349-367. 
Frank, Thomas. 2004. What's the Matter with Kansas? How Conservatives Won the Heart of America. New York: Metropolitan Books.

Glaeser, Edward L., Giacomo A. M. Ponzetto, and Jesse M. Shapiro. 2004. Strategic Extremism: Why Republicans and Democratic Divide on Religious Values. Cambridge, MA: Harvard Institute of Economic Research, Discussion Paper Number 2044.

Green, John C., and James L. Guth. 1991. The Bible and the Ballot Box: The Shape of Things to Come. Pp. 207-225 in The Bible and the Ballot Box: Religion and Politics in the 1988 Election, eds. James L. Guth and John C. Green. Boulder, CO: Westview.

Green, John C., James L. Guth, and Kevin Hill. 1993. Faith and Election: The Christian Right in Congressional Campaigns, 1978-1988. Journal of Politics 55:80-91.

Hillygus, D. Sunshine, and Todd G. Shields. 2005. Moral Issues and Voter Decision Making in the 2004 Presidential Election. PS: Politics and Political Science 38: 201-209.

Hunter, James Davison. 1991. Culture Wars: The Struggle to Define America. New York: Basic.

Hutcheson, Richard G., Jr., and Peggy L. Shriver. 1999. The Divided Church: Moving Liberals and Conservative from Diatribe to Dialogue. Downers Grove, IL: InterVarsity Press.

Jackman, Simon. 2004. Same-Sex Marriage Ballot Initiatives and Conservative Mobilization in the 2004 Election. Retrieved August 20, 2007 from http://jackman.stanford. edu/papers/RISSPresentation.pdf.

Jacobson, Gary C. 2007. A Divider, Not a Uniter: George W. Bush and the American People. New York: Longman.

Jelen, Ted G. 1991. The Political Mobilization of Religious Beliefs. New York: Praeger.

Jelen, Ted G., and Clyde Wilcox. 2003. Causes and Consequences of Public Attitudes Toward Abortion: A Review and Research Agenda. Political Research Quarterly 56:489-500.

Kaufmann, Karen M. 2002. Culture Wars, Secular Realignment, and the Gender Gap in Party Identification. Political Behavior 24:283-307.

Kellstedt, Lyman A., and Corwin E. Smidt. 1996. Measuring Fundamentalism: an Analysis of Different Operational Strategies. Pp. 193-218 in Religion and the Culture Wars: Dispatches from the Front, eds. John C. Green, James L. Guth, Lyman A. Kellstedt, and Corwin E. Smidt. Lanham, MD: Rowman and Littlefield.

King, Gary, Michael Tomz, and Jason Wittenberg. 2000. Making the Most of Statistical Analyses: Improving Interpretation and Presentation. American Journal of Political Science 44:347-361.

Kuckey, Jonathan. 2005. A New Front in the Culture War? Moral Traditionalism and Voting Behavior in U.S. House Elections. American Politics Research 33:645-671.

Larson, Edward J. 1997. Summer of the Gods: The Scopes Trial and America's Continuing Debate over Science and Religion. New York: Basic.

Lawrence, Jill. 2002. Values, Votes, and Points of View Separate Towns and Nation. USA Today, February 18, p. A10.

Layman, Geoffrey C. 1997. Religion and Political Behavior in the United States: The Impact of Beliefs, Affiliations, and Commitment from 1980 to 1994. Public Opinion Quarterly 61:288-316.

Layman, Geoffrey C. 2001. The Great Divide: Religious and Cultural Conflict in American Party Politics. New York: Columbia University Press. 
Layman, Geoffrey C., and Edward G. Carmines. 1997. Cultural Conflict in American Politics: Religious Traditionalism, Postmaterialism, and U.S. Political Behavior. Journal of Politics 59:751-777.

Marsden, George M. 1980. Fundamentalism and American Culture: The Shaping of 20th Century Evangelicalism, 1870-1925. New York: Oxford University Press.

McCarty, Nolan, Keith T. Poole, and Howard Rosenthal. 2006. Polarized America: The Dance of Ideology and Unequal Riches. Cambridge, MA: MIT Press.

McElvaine, Robert S. 2004. Red State; Blue State; A Democrat's Lonely Stand. Washington Post, October 10, p. B1.

Mouw, Ted, and Michael Sobel. 2001. Culture Wars and Opinion Polarization: The Case of Abortion. American Journal of Sociology 106:913-943.

Mutz, Diana C. 2006. How the Mass Media Divide Us. Pp. 223-48 in Red and Blue Nation?, eds. Pietro S. Nivola and David W. Brady. Washington, DC: Brookings.

National Exit Poll. 2004. National Exit Poll Results: Presidential Election. Washington Post, November 2. Retrieved February 1, 2007 from http://www.washingtonpost. com/wp-srv/politics/elections/2004/graphics/exitPolls national.html.

Newport, Frank. 2005. Church Attendance and Party Identification. The Gallup Organization, May 18.

O'Connor, Karen. 1996. No Neutral Ground? Abortion Politics in an Age of Absolutes. Boulder, CO: Westview.

Olson, Laura R., and John C. Green. 2006. The Religion Gap. PS: Political Science and Politics 39:455-459.

Pew Center for People and the Press. 2001. Faith-Based Funding Backed, but ChurchState Doubts Abound. Retrieved August 20, 2007 from http://people-press.org/ reports/display.php3?PageID=111.

Rozell, Mark J., Clyde Wilcox, and John C. Green. 1998. Religious Constituencies and Support for the Christian Right in the 1990s. Social Science Quarterly 79:815-827.

Smith, Kevin B. 1994. Abortion Attitudes and Vote Choice in the 1984 and 1988 Presidential Elections. American Politics Quarterly 22:354-369.

Spong, John Shelby. 1991. Rescuing the Bible from Fundamentalism. New York: Harper Collins.

Sullins, D. Paul. 1999. Catholic/Protestant Trends on Abortion: Convergence and Polarity. Journal for the Scientific Study of Religion 38:354-369.

Tedin, Kent, David Brady, Mary Buxton, Barbara Gorman, and Judy Thompson. 1977. Social Background and Political Differences between Pro- and Anti-ERA Activists. American Politics Quarterly 5:395-408.

Tomz, Michael, Jason Wittenberg, and Gary King. 2001. CLARIFY: Software for Interpreting and Presenting Statistical Results. Cambridge, MA: Harvard University, June 1.

Verba, Sidney, Kay Lehman Schlozman, and Henry E. Brady. 1995. Voice and Equality: Civic Voluntarism in American Politics. Cambridge, MA: Harvard University Press.

White, John Kenneth. 2003. The Values Divide. Chatham, NJ: Chatham House.

Wilcox, Clyde, and Carin Larson. 2006. Onward Christian Soldiers: The Religious Right in American Politics, 3rd ed. Boulder, CO: Westview.

Wuthnow, Robert. 1988. The Restructuring of American Religion. Princeton, NJ: Princeton University Press. 